\title{
Features of the international manager- leader of the near future - findings of the research
}

"Every great manager has his own style.

But they all share a common goal: transform the talent of each employee into his achievements.

Four keys - finding talent, identifying the desired results, focus on strengths and appropriate adjustment - show how they attack this goal."

(Buckingham, 2001, p. 285)

\section{Introduction}

Manager-leader is nowadays an often used term for an effective person, successfully managing an organization and people. There is a common belief that the success of the organization is the success of "efficient" manager, and the failure of the organization is identified with the ineffective management. Despite the many studies done on the list of leadership qualities and the phenomenon of leadership, knowledge of the subject does not allow to propose one specific model and still "remains at the level of hypothesis" (Kuc 2016, p. 163).

Addressing for several years by the author of this paper the issues of internationalization and international management, allowed for conducting the research and reasoning also

Beata Glinkowska, Ph.D University of Lodz Department of Management into the list of qualities of manager-leader who manages the enterprise already functioning in the international market, or trying to 
enter the market. Over the last three years tests have been conducted in fifty Polish enterprises of production, trade and service character, which directly or indirectly cooperated with entities outside the home country. The vast majority of the surveyed companies (89\%) are located in the Lodz region. Research is conducted within the framework of statutory activity (KZ/4/S/NB/2015) and within the framework of own research. They are successively continued and developed. Since 2015 their scope has been expanded to the market of Ukrainian enterprises. This is possible through scientific and research collaboration with T. Shevchenko National University of Luhansk. However, the complicated military and political situation in Ukraine is the reason why the research process is slow, hence the results of the research are planned to be presented in about a year and half. The research tool is a structured questionnaire and interview questionnaire with the possibility of free expression. Questions were directed to middle level managers and line managers and to specialists in various departments in companies that directly or indirectly conduct business on foreign markets or with foreign companies. A total of eighty respondents from the abovementioned companies were asked about desirable traits of manager-leader of the near future. Targeted selection was used. The main objective of this paper is therefore to present a list of desirable features of an international managerleader of near future. The cafeteria of characteristics in the questionnaire was based on the existing in the literature suggestions which are presented in point 3 and 4 of this study. The research is subjective because - as the author assumes - only the future can verify its relevance. The study may therefore become the basis for verification of this list in the near future. By "near future" the author means the coming years (1-5) and sees the difference between the near future and the future in such a way that the future is more distant and less definite from the point of view of predictability of the directions of development of economies, enterprises and desirable attributes of the manager. Manager-leader is a person who possesses not only technical, conceptual, social skills, but also a set of personality traits. There have also been attempts to answer the question, which of the terms: manager, leader, or director, the respondents associated with the success of organization to the greatest and which to the least extent.

\section{The nature and definitional approach to concepts: manager and leader}

The term 'manager' is in the literature often used interchangeably with terms such as leader, supervisor, director and is derived from an English word "manage", which means to manage, to direct. 
P.F. Drucker identifies the manager with the possession of the authority of knowledge, professionalism, ability to adapt to change, the ability to solve problems, effectiveness in action, practicality, rationality and firmness (see: Kubik 2012, p. 13). According to him, not every supervisor is a manager, for example a foreman is not. Whereas T. Listwan (1995, p. 16) recognizes as managers all the staff who occupy superiors' positions - from the master through to the chairman - that is all those responsible for shaping and coordinating the work of others. Managers are identified by him with whitecollar workers (specialists), who are required to take strategic decisions with a significant impact on the achievements and results of the organization (Drucker, 1994, p. 17-20). P. Wachowiak (2001, p. 19) defines manager as a person who should influence the behaviour of subordinates so that they realize their goals. R.W Griffin (2004, p. 5-14) names as managers those whose main task is the implementation of the management process. K. Kubik (2005, p. 72) adds that he perceives them as directors, administrators, managers, supervisors and heads of teams. L. Herber (1998, p. 25) believes that the manager is an employee, delegated by the owner of the company, who on his behalf makes decisions about the distribution of resources. Some researchers consider the manager a person who is responsible for the effective management of activities aimed at achieving the objectives of the organization (Stoner, Freeman, Gilbert 2001, p. 19). Therefore, manager can be considered a representative of the organization, acting alone, but directing all or part of the work of its employees, caring about its development and values. So who is the leader, or managerleader? In today's world there is no doubt about the importance of leadership as a key to the success of the organization. State of the art technical facilities, large financial resources and highly qualified personnel count only when effective leadership creates the appropriate conditions for use of this potential. It should be emphasized that effective leadership allows achieving success with even minimal financial resources, property and human resources of the organization. For this reason, it is taken for granted that the modern supervisor or manager should be a leader; because the efficiency of his work grows as measured by the degree of achievement of the objectives through the work of others and with others. The leader is a person exerting influence on the conduct of other members of the group (team), what is important: having the same goal (Chmiel 2003, p. 308). M. Kostera emphasizes that leadership can be identified with the person of the leader and his characteristics, the results of operations, his formal position or with the process (Kostera (ed.) 2008, p. 332). Analysis of literature on the subject allows for putting forward a thesis that effective 
leadership has a major impact on the success of the organization (Austen 2010, p. 26). Today the manager-leader is seen as a high-class professional managing the company and through it - the people, responsible for the talent search and their management, as well as for the implementation of the strategic plan. In summary, we should clearly distinguish between the management process, which is identified with the person of the manager, and the process of leading, identified with the person of the leader. R.W. Griffin also distinguished the differences between management and leadership in four areas (Griffin 2004, p. 554-555):

1. Creation of the program. Here, management focuses on planning and budgeting. The leaders in this area deal primarily with formulating a vision for the organization and its future-oriented strategy.

2. Drafting organizational structure for its implementation. In this area, the role of management is to organize the structure, staff the jobs, allocate tasks and powers, also specify the procedures and control systems. Leadership consists rather in the creation of teams who understand and accept the proposed vision and strategy for its implementation, through words and deeds.

3. Performance. For the management process the implementation of the plan is mainly a detailed inspection and corrective actions; whereas for the leadership these measures are primarily related to motivating and inspiring to action.

4. Results. In this area, management seeks to identify the extent of the performance, organization and systematization. The purpose of leadership, however, is the creation of innovative and important changes.

Some researchers emphasize and the author of this study agrees with them, that in the organization it is necessary to carry out both the management functions associated with managerialism and leadership. The combination of the two processes: management and leadership can give a synergy effect.

\section{Characteristics of the modern manager-leader}

Global competition and the liberalization of markets put new goals and new functions before the managers who in shaping those goals and functions must consider who their implementation depends on as well as how to better and faster implement them. P. Drucker (1994) stresses that an important role in achieving the objectives plays motivating people and informing them of the steps, results, effects, evaluations, obtained indicators, the consequences for the environment. A manager should help people to develop, choose a course of action, skilfully guide them, but also him. An effective manager builds on 
the strengths of his own and his subordinates (see Bartkowiak 2002, pp. 12-13). According to P. Wachowiak (2001, p. 15), a modern manager should be not only effective, but also have a passion and desire to direct.

Global and international competition triggers the emergence of many new problems, requirements and behaviours. All this nonstop force the managers to improve themselves and to assist with the improvement of employees and processes. "Inspiring (...) for constant development of personality and creative invention, that is managing through leading" (Hoening 2006, p. 37) is determinant for effectiveness of managers-leaders. The changing world and ever growing requirements of the organization's environment make the expectations towards the manager change too. Such circumstances change the sense of managerial roles from classical to the so-called $3 \mathrm{~W}$, understood as requiring, tying and supporting (Hoening 2006, p. 37). J. Penc (2005, pp. 69-71) pays particular attention to mental predispositions of manager-leader, which include: ability to understand and communicate with people (and not only to communicate), awareness of responsibility for actions, sense of teamwork, patience, concentration on a speaker, perseverance and persistence in pursuing the goals, stress resistance, creativity in thinking and action.

The effectiveness and ability of leadership is connected with the formula of 3E, which - apart from effectiveness and economy of management - lists also its ethics (Bogdanienko 2013, p. 14). Modern manager-leader should possess specific qualifications, such as making and developing contacts with the environment, skilfully handling negotiations, enthusiastically motivating subordinates, capably solving conflicts (Mintzberg 2010; Stoff 2009, p. 41). He has to show willingness and ability to learn, flexibility as well as selfconfidence, self-discipline, perseverance and consequence in action. He should realize his goals in ethical way in accordance with principles and moral values. He should be ambitious and prioritize self-realization and constantly gaining new experience as well as developing and improving skills (Tybińkowski, Kazura 2005).

It must be an assertive person, resistant to stress, able to manage time efficiently. Any qualities connected with interpersonal skills - easiness in making contacts and building relations and communication, positive attitude and empathy - are of key importance to the success of manager-leader. Other important qualities of a manager-leader are ability to solve conflicts (including management of emotions and their control). To sum up, it can be noticed that efficiency and effectiveness of leadership emphasize the big role of soft competences, reducing the significance of hard competences, like technical skills. 


\section{Qualities of the manager-leader of the future}

E.H. Schein believes that managers of the future will have to demonstrate the following qualities:

- exceptionally high level of perception and insight into themselves and their surroundings,

- exceptionally high level of motivation in self-realization,

- great emotional strength in order to keep calm in stressful situations,

- ability to analyze cultural premises and multiculturalism, building strong enthusiastic organizational culture based on the respect for the value of an individual,

- ability to engage the participants of the organization and gaining their active participation in problem-shooting,

- ability to share power, delegate warrants in accordance with the people's skills and abilities (see: penc 2005, pp. 73-74).

C. Handy believes that manager should have such qualities as (Penc 2005, pp. 69-71):

- faith in own powers,

- courage allowing for acknowledging own mistakes,

- passionate commitment to work,

- love for people.

The above-mentioned qualities of manager -leader of the future should be complemented with those given by C.K. Prahalad (1998, pp. 191-192). According to this researcher, manager of the future should be characterised by:

1. Ability to systemic thinking. Combination of systemic and conceptual thinking allows the manager to discern ties between specific elements of the organization. Manager-leader of the future should be able to analyze but also to synthesize the obtained information, have intuition, distinguish between private and public interest.

2. Ability to function in multicultural environment. This ability means command of foreign languages, knowledge of cultures of given countries, their history, values and religions.

3. Orientation on constant learning. Managers of the future have to be all the time ready to accept new ideas, new customs, technologies, economic practices. Current knowledge is getting out of date at a fast rate so managers are obliged to look for possibilities of constant self-development as well as development of their subordinates. It is a necessary condition for the development of the whole organization. 
4. Positive personality traits, attitudes and high standards of conduct. Establishing the standards of values and behaviours required by the company as well as support and evoking motivation and enthusiasm appear to be duties of the manager of tomorrow who also wants to and is able to take responsibility for his actions.

Psychologists who study determinants of the manager's success are of opinion that there exist personality traits which are conducive to success in management of organizations. They include: hardworking, flexibility, social maturity, ability to think logically, swiftness of decision-making and tendency to improvement (Kubik 2012, pp. 25-26).

Psychological traits also include intellectual agility, temper and personality. Significance of these traits grows together with the increase in complexity of the organization.

$\mathrm{R}$ Tomlinson counts into manager-leader's qualities the following: ability to formulate goals, build up visions, take justifiable risks and strategic decisions, ability to build teams, support and motivate them, ability to communicate and convey information (Tomlinson 2010, p. 24).

New conditions of functioning of the managers (increasingly in international environment) force them to generate added value which appears to be primary social duty of the organization. Managers can fulfil this social duty by developing new ideas or by using creativity and enthusiasm of the workers as well as by building multifunctional and multidisciplinary teams (Jamali 2005, p. 109). These qualities should also include the ability to take responsibility for the course of events and decisions taken as well as awareness of the direction which needs to be followed (Handy 1997, p.34).

To sum up, manager-leader of the future should have an open worldview and be happy, should be committed to the organization and the workers but also maintain work-life balance, be ethical, moral and look through the prism of sustainable development in running business activities (Glinkowska 2015, pp. 83-92). Happy man is able to notice those aspects and threads which are invisible to the others. The social responsibility of the organization is something which cannot be ignored or put in the shade in the future.

\section{Qualities of international manager-leader of the near future in the light of own research}

Managers constitute a numerous professional group in Poland. Summarising data regarding the number of persons employed on managerial positions and 
the number of persons running their own businesses, it can be assumed that the total number of managers in Poland in 2011 was approximately 2 million Jarmołowicz,Kościńskihttp://mikroekonomia.net/system/publication_ files/367/original/19.pdf?1314957341dostęp dn.:03.02.20167).

Managers more and more often operate in international environment, which imposes on them additional duties, new challenges, is a reason why they solve new complex problems. They are faced with the necessity to possess the ability to function in a multicultural environment and to build multicultural teams. The future has to determine a new type of manager-leader, who in such a complex international environment will find their place and be successful. Therefore, what desired traits should a manger-leader of the near future have?

This question was stated before purposefully selected middle level managers and line managers as well as specialists from different departments of companies cooperating with foreign enterprises (directly or indirectly). It allowed for reducing some subjectivism which might have been a result of questioning the highest level management. Interviewing the specialists and middle level and line managers and specialists, selected also purposefully, allows for obtaining the answer which is quite objective, is a result of own reflections and experience and expectations towards their superiors. It is not possible, however, to eliminate lack of measurability of the results obtained because - as it was already mentioned in the Introduction - they can only be verified in a few years time. In total, 80 respondents were asked (by means of survey questionnaire) about the desired traits of a manager-leader of the near future and the aim of the study is to present the findings.

Respondents received a list of qualities and abilities of a manger-leader of the near future. Their task was to arrange the traits in order of importance (in their opinion). Table 1 presents collectively the proposed categories and the answers obtained.

Table 1. Qualities and abilities of manager-leader of near future - cafeteria

\begin{tabular}{r|l|l}
\hline Item & Qualities/ abilities & $\begin{array}{c}\% \text { answers } \\
\text { and number of } \\
\text { respondents }\end{array}$ \\
\hline 1 & Ability to create visions and formulate goals & $100 \%$ (80 persons) \\
\hline 2 & Ability of conceptual thinking and acting & $100 \%$ (80 persons) \\
\hline 3 & Ability to communicate & $100 \%$ (80 persons) \\
\hline
\end{tabular}




\begin{tabular}{|c|c|c|}
\hline 4 & Supporting and motivating mentoring, coaching & $100 \%$ (80 persons) \\
\hline 5 & Ability to listen and Draw conclusions & $100 \%$ (80 persons) \\
\hline 6 & Honesty, fairness, ethical and moral conduct, social responsibility & $96.25 \%$ (77 persons) \\
\hline 7 & $\begin{array}{l}\text { Ability to cooperate with multicultural teams and to create } \\
\text { multicultural teams }\end{array}$ & $92.50 \%$ (74 persons) \\
\hline 8 & Enthusiasm and energy & $88.75 \%$ (71 persons) \\
\hline 9 & Resistance to stress & $88.75 \%$ (71 persons) \\
\hline 10 & Persistance In pursuing goals & $87.50 \%$ (70 persons) \\
\hline 11 & Ability to step beyond commonplace standards and to take risks & $86.25 \%$ (69 persons) \\
\hline 12 & Ability to acknowledge good ideas (put forward by subordinates) & $81.25 \%$ (65 persons) \\
\hline 13 & Ability to look for chances & $80 \%$ (64 persons) \\
\hline 14 & Openess and flexibility & $75 \%$ (60 persons) \\
\hline 15 & Ability to make decisions & $65 \%$ (52 persons) \\
\hline 16 & Ability to learn & $63,75 \%$ (51 persons) \\
\hline 17 & Creativity and inspiring others & $60 \%$ (48 persons) \\
\hline 18 & Ability to investigate and obtain new knowledge & $60 \%$ (48 persons) \\
\hline 19 & Ability to plan and organize & $57.50 \%$ (46 persons) \\
\hline 20 & Command of foreign languages & $42.50 \%$ (34 persons) \\
\hline 21 & Ability to conduct negotiations & $40 \%$ (32 persons) \\
\hline 22 & Expertise in the latest communication technologies & $35 \%$ (28 persons) \\
\hline 23 & Ability to think analytically & $23.75 \%$ (19 persons) \\
\hline 24 & Ability to control and identify mistakes & $17.50 \%$ (14 persons) \\
\hline
\end{tabular}

Source: own study

From the analysis of the table it transpires that manager-leader of the near future should to the greatest extent possess the following qualities:

- ability to create visions and formulate goals,

- ability of conceptual thinking and acting, 
- ability to communicate,

- supporting and motivating, mentoring, coaching,

- ability to listen and draw conclusions,

- honesty, fairness, ethical and moral conduct, social responsibility,

- ability to cooperate with multicultural teams and ability to build multicultural teams,

- enthusiasm and energy,

- resistance to stress,

- persistence in pursuing goals.

The first five qualities/abilities are for the respondents the most important and equally significant. They were indicated by $100 \%$ of respondents. The least important (below $50 \%$ frequency of indication) are qualities such as:

- command of foreign languages,

- ability to conduct negotiations,

- expertise in the latest communication technologies,

- ability to control and identify mistakes.

Confronting the findings of the author's own research with those obtained by the American company Ken and Feny ${ }^{1}$, it transpires that highly ranked are such qualities as enthusiasm and energy ( $92 \%$ respondents indicated this quality as compared to $88.75 \%$ in author's own research), openness and flexibility ( $88 \%$ and $75 \%$ respectively), honesty, fairness, ethical and moral conduct, social responsibility (84\% versus 96.25\%) (Ogger 2004, p. 252; own research).

Consecutively confronting the findings of the author's own research and the findings obtained by the International Managers Agency (TASA) in Brussels, it transpires that such qualities as manager-visionary, manager who is flexible, patient, responsible for decisions taken, respectful towards subordinates, communicative, binding different views and attitudes of workers for the sake of the company, are the most important (Penc 2010, p. 89).

Then, comparing the findings of the author's own research with those obtained by "Rzeczpospolita" , it transpires that among the most important qualities of manager-leader are: experience in management (53.1\% respondents), ability to make swift decisions (52.7\%),

1 Research conducted on a group of approximately 1500 managers from different countries (American, European and Japanese) of the highest qualifications.

2 Research on a group of 850 Polish managers conducted in 2000. Among the respondents there were $38 \%$ of owners or shareholders of the companies where they function as managers. 
Expertise (48.0\%), entrepreneurship and initiative (46.8\%), care for workers $(15.9 \%)$, communicativeness $(19.4 \%)$, broad knowledge $(11.5 \%)$, strong individualism (18.1\%) and intuition (20.05\%). As it can be seen these qualities and abilities diverge from those obtained from the author's own research (except the ability to make decisions) (Koźmiński 2008, p. 26).

\section{Conclusions}

Summarising the considerations on manager-leader of the near future, it can be said that there is a growing demand for the so-called soft competences and the ability to create vision, to communicate, support and motivate, mentor and coach. The area of ethics and morality of a modern manager is a dimension of new challenges which is also gaining more and more importance. It ought to be thought that in the near future we should seek right proportions and integration of actions aimed at ensuring the development of the organization and good economic results with the inclusion and respect for the principles for all stakeholders. The manager-leader of the future is expected to be able to seek and work out give-and-take solutions for often conflicting interests instead of escalating tension and conflicts. The attitude and organizational behaviours of the managers are strongly conditioned by (and dependent on) the influences of endogenous and exogenous factors; however, manager-leader of the future is supposed to have ability to communicate, negotiate, listen and draw conclusions. He is to be ethical, moral and socially responsible initiator, able to work in a multicultural environment. His personality traits based on the ability to listen, support, and shape emotional intelligence will be particularly desirable.

\section{Summary}

\section{Qualities of manager-leader of the near future - results of the research}

The paper covers characteristics of the conducted research, including definitional approach to the essence of the terms: manager and leader. Particular attention was paid to the qualities of modern manager-leader and the qualities of manager-leader of the future, including globalization and internationalisation. The research part contains findings of the author's own research which were confronted with the results of studies existing in this area in the subject literature. 
Keywords: manager, manager-leader, organization, enterprise.

\section{Streszczenie}

\section{Cechy menedżera-przywódcy niedalekiej przyszłości - wyniki badań}

W opracowaniu zawarto charakterystykę przeprowadzonych badań, także definicyjne ujęcie istoty pojęć: menedżer i przywódca. Szczególna uwaga została skoncentrowana na cechach współczesnego menedżera-przywódcy i cechach menedżeraprzywódcy przyszłości, uwzględniając zjawiska globalizacji i internacjonalizacji. W części badawczej zawarto wyniki badań własnych, które skonfrontowano $\mathrm{z}$ istniejącymi w tym obszarze wynikami badań w literaturze przedmiotu.

\section{Słowa}

kluczowe: menedżer, menedżer-przywódca, organizacja, przedsiębiorstwo.

\section{References}

1. Austen A. (2010), Efektywność przywództwa w organizacji publicznej [in:] Organizacja i zarządzanie No. 4(12), Wydawnictwo Politechniki Śląskiej, Gliwice.

2. Bartkowiak G., (2002) Skuteczny kierownik - model i jego empiryczna weryfikacja, Wydawnictwo Akademii Ekonomicznej w Poznaniu, Poznań.

3. Bogdanienko J. (2013), W. Piotrowski, Zarządzanie. Tradycja i nowoczesność., PWE, Warszawa.

4. Buckingham M. (2001), Po pierwsze: złam wszelkie zasady. Co najwięksi menedżerowie na świecie robia inaczej, MT Biznes, Warszawa.

5. Chmiel N. (2003), Psychologia pracy i organizacji, Gdańskie Wydawnictwo Psychologiczne, Gdańsk.

6. Drucker P.F. (1994), Menedżer skuteczny, Akademia Ekonomiczna, Kraków.

7. Glinkowska B. (2015), Współczesne ujęcie roli menedżera w organizacji pracy w handlu w świetle badań własnych, „Przedsiębiorczość i Zarządzanie", Vol. XVI, No. 9 part I.

8. Griffin R.W. (2004), Podstawy zarzadzania organizacjami, wyd. II zm., Wydawnictwo Naukowe PWN, Warszawa.

9. Haber L.W. (1998), Management, Zarys zarzadzania mała firma, WPSB, Kraków.

10. Handy Ch. (1997), Nowy język organizacji i jego znaczenie dla klientów, [in:] F. Hesselbein, M. Goldsmith, R. Beckhard, Lider przyszłości, Business Press, p. 34. 
11. Hoening R. (2006), Umiejętność kierowania ludźmi coraz cenniejsza, "Zarządzanie na świecie" No. 7.

12. Jamali D. (2005), Changing management paradigms: implications for educational institutions, "Journal of Management Development", Vol. 24, No. 2.

13. Jarmołowicz W., Kościński M., Menedżer - na polskim i wielkopolskim rynku pracy - portret wlasny, http://mikroekonomia.net/system/publication_files/367/ original/19.pdf?1314957341 (03.02.2017 - access date).

14. Kostera M (ed.) (2008), Nowe kierunki w zarzadzaniu, Wydawnictwa Akademicki i Profesjonalne, Warszawa.

15. Koźmiński A.K. (2008), Koniec świata menedżerów, Warszawa, Wyd. WAiP.

16. Kuc B.R. (2016), Paradoksy przywództwa: Od szamana do skowmana, Wyd. Ementor, Warszawa.

17. Kubik K. (2005), Menedżer w przedsiębiorstwie przyszłości, Towarzystwo Naukowe Organizacji i Kierownictwa „Dom Organizatora”, Torun.

18. Kubik K. (2012), Menedżer w procesie zarzadzania zasobami ludzkimi, Wyd. PTM, Warszawa.

19. Listwan T. (1995), Kształtowanie kadry menedżerskiej firmy, Wydawnictwo „KADRY”, Wrocław.

20. Mintzberg H. (2010), The Manager's Job, „Harvard Business Review”, No. 2.

21. Ogger G. (2004), Zera w garniturach, Wyd. WPSB Kraków.

22. Penc J. (2005), Role i umiejętności menedżerskie. Sekrety sukcesu i kariery, Difin, Warszawa.

23. Prahalad C.K. (1998), Rola menedżerów nowej ery na konkurencyjnym rynku [in:] Hesselbein F., Goldsmith M., Bechard R. (eds.), Organizacja przyszłości, Businessman Bock, Warszawa.

24. Stoff W.D. (2009), Nowe role menedżera, "Zarządzanie na świecie”, No. 3.

25. Stoner J.A.F, Freeman R.E., Gilbert D.R. (2001), Kierowanie, PWE, Warszawa.

26. Tybińkowski D., Kazura A. (2005), Charakterystyka nowoczesnego menedżera [in:] Szybkobieżne Pojazdy Gąsienicowe No. 21, Ośrodek BadawczoRozwojowy Urządzeń Mechanicznych „OBRUM” sp. z o. o., Gliwice.

27. Tomlinson R. (2010), Nowe myślenie elity menedżerskiej w Europie, "Zarządzanie na świecie" No. 5.

28. Wachowiak P. (2001), Profesjonalny menedżer, Wyd. Difin, Warszawa. 